Dear Author,

Please, note that changes made to the HTML content will be added to the article before publication, but are not reflected in this PDF.

Note also that this file should not be used for submitting corrections. 


\title{
In stable, unmanaged grasslands local factors are more important than landscape-level factors in shaping spider assemblages
}

\author{
3 Q1 Roland Horváth ${ }^{a}$, Tibor Magura ${ }^{a, *}$, Csaba Szinetár ${ }^{b}, J^{\prime}$ nos Eichardt ${ }^{b}$, Éva Kovács ${ }^{c}$, \\ Béla Tóthmérész ${ }^{\mathrm{d}}$ \\ a Department of Ecology, University of Debrecen, PO Box 71, H-4010 Debrecen, Hungary \\ b Department of Zoology, University of West Hungary, PO Box 170, H-9700 Szombathely, Hungary \\ ' Kiskunság National Park Directorate, PO Box 186, H-6001 Kecskemét, Hungary \\ ${ }^{\mathrm{d}}$ MTA-DE Biodiversity and Ecosystem Services Research Group, Egyetem tér 1, H-4032 Debrecen, Hungary
}

\section{A R T I C LE I N F O}

Article history:

Received 20 January 2015

Q3 Received in revised form 27 April 2015

Accepted 30 April 2015

Available online $\mathrm{xxx}$

\section{Keywords:}

9-Year period

Habitat affinity

Hunting spiders

Plant cover

Bare ground cover

Dry sandy grasslands

\section{A B S T R A C T}

Previous studies reported that landscape-level factors are vital to support diversity of spiders in strongly modified arable lands and disturbed habitats such as managed semi-natural grasslands. Cropland management (ploughing, fertilization, and pest management) and agricultural practices (mowing and grazing) destroy and/or modify regularly the spider assemblages; thus, continuous recolonization from the surrounding landscape is vital to sustain the species pool. On the contrary, we hypothesized that in unmanaged grasslands, the spider assemblages are stable and the importance of recolonization is limited, the local factors become much more important drivers in shaping spider assemblages than landscape-level factors. We tested the importance of local and landscape-level factors on the abundance and species richness of spiders in unmanaged grasslands. At the landscape-level, we found that only the isolation had significant effect on the total abundance, on the abundance of hunting and habitat specialist species, and on the abundance of a frequent species (Gnaphosa mongolica). At the local scale, however, four out of five studied factors influenced significantly the species richness and abundance of spider assemblages and the abundance of two frequent species (Alopecosa psammophila, Berlandia cinerea). Species richness and abundance increased by plant cover, litter cover, and patch size, while decreased by bare ground cover. We found that in unmanaged grasslands, the local factors had vital role in maintaining the spider species richness; this is just the opposite conclusion that was earlier reported for agricultural ecosystems, where landscape-level effects had crucial role providing the species for continuous recolonization.

(c) 2015 Published by Elsevier B.V.

\section{Introduction}

Prior to agricultural intensification, natural and semi-natural grasslands were one of the most diverse habitat types in Europe (Batáry et al., 2008). Since the second half of the last century, the increasing agricultural activity has been an important driver of biodiversity loss in these grasslands (Tscharntke et al., 2005; Krauss et al., 2010; Hooftman and Bullock, 2012; Dengler et al., 2014). Low-intensity grassland systems in Central and Eastern Europe maintain a diverse and unique fauna and flora (Varga, 1997;

\footnotetext{
* Corresponding author. Tel.: +36 52512 900; fax: +36 52512743.

E-mail addresses: horvath.roland@science.unideb.hu (R. Horváth), maguratibor@gmail.com (T. Magura),szcsaba.bdtf@gmail.com (C. Szinetár), ejanek@gmail.com (J. Eichardt), kovacse@knp.hu (É. Kovács), tothmerb@gmail.com (B. Tóthmérész)
}

Török et al., 2000). During the last decades due to the increase of large-scale farming and abandonment of the traditional management practices, the Central and Eastern European grasslands also become highly fragmented and endangered (Horváth et al., 2009; Buchholz, 2010).

Grasslands play an important role in the maintenance of biodiversity in cultivated landscapes by providing habitats and/or refuges for many species (Jeanneret et al., 2003; Woodcock et al., 2005; Horváth et al., 2013). Survival of the majority of grassland arthropod species in cultivated landscapes primarily depends on the quality of habitats, but also depends on the surrounding landscape (Jeanneret et al., 2003). To understand the relationship between agricultural activity and grassland biodiversity, it is essential to investigate the effects at different spatial scales (e.g., the local scale and the landscape-level scale) in these habitats (Tscharntke et al., 2005, 2012; Batáry et al., 2008). 
Spiders are one of the most abundant and species rich generalist predators. They contribute to the biodiversity in natural and agricultural ecosystems (Wise, 1993). The occurrence of spiders mostly depends on local factors such as vegetation structure, vegetation composition, microclimate conditions, and prey availability (Heikkinen and MacMahon, 2004; Horváth et al., 2005; Batáry et al., 2008; Schirmel et al., 2011). Landscape-level factors such as percentage of grasslands, percentage of non-crop habitats, and landscape diversity also influence spider assemblages (Clough et al., 2005; Horváth et al., 2013; Schmidt et al., 2008). Q5 Moreover, the human disturbance (urbanization and fragmentation), natural disturbance (e.g., fire, flood, and drought), and management regime (mowing, grazing, and burning) are also important factors (Cattin et al., 2003; Horváth et al., 2009, 2012; Malumbres-Olarte et al., 2014). To understand the changes in structure and composition of spider assemblages in natural and semi-natural habitats, it is important to investigate the effects of environmental factors at both local and landscape-level scales (Batáry et al., 2008).

In the previous studies, the effects of local and landscape-level factors on spiders were mainly investigated in strongly modified habitats such as arable lands (Clough et al., 2005; Schmidt et al., 2005, 2008; Öberg et al., 2007; Concepción et al., 2008; Drapela et al., 2008; Pluess et al., 2010) and in managed (grazed or mowed) semi-natural grasslands (Hendrickx et al., 2007; Batáry et al., 2008, 2012; Miyashita et al., 2012; Zulka et al., 2014). Surprisingly, the assessment of the importance of local and landscape-level factors on the assemblages of unmanaged grasslands is still missing. We would like to stress that there is an essential difference between the spider assemblages living in strongly modified, disturbed habitats, and those inhabiting unmanaged habitats. Assemblages in modified, disturbed habitats are regularly disrupted, therefore, recolonization from the surrounding landscape may be permanent, while assemblages in unmanaged habitats are more stable, and therefore, the role of the recolonization may be less important. Therefore, it is important to test the influence of the local and landscape-level factors in these unmanaged habitats.

In this study, our aim was to test the effects of local and landscape-level factors on the spider species richness and abundance. We also tested the effects of local and landscape-level factors on the abundance of the most frequent hunting spider species. We hypothesized that spider species richness and abundance increase with increasing cover of plants and litter, average height of grass and patch size but decrease with increasing bare ground. We supposed that in unmanaged grasslands, the spider assemblages are stable; therefore, the effects of landscapelevel factors (isolation and landscape diversity) are less important in shaping spider assemblages than local factors. Moreover, we also hypothesized that most frequent hunting species respond heterogeneously to both local and landscape-level factors due to their variability in habitat affinity and ecological demands.

\section{Methods}

\subsection{Study area}

We selected nine unmanaged dry sandy grassland fragments in the Kiskunság region (size: 30,628 ha) of the Hungarian Great Plain which is located between the Danube and the Tisza rivers (Central Hungary) (Table 1). All selected sampling sites have the same vegetation type; these fragments are embedded in the same matrix. The typical grassland vegetation of the unmanaged dry sandy grassland fragments was Festucetum vaginatae danubiale (Szinetár et al., 2005). The relative abundance of protected plant species can exceed $26 \%$ in these grasslands (Török et al., 2000). Wetlands, forests (native and planted), and arable fields surrounded all the investigated grassland fragments. Thus, the habitat matrix was similar for all the studied grassland fragments. The Kiskunság region lies in the warm temperate zone with an annual mean temperature between 10.2 and $10.8^{\circ} \mathrm{C}$. The annual mean precipitation is $550-600 \mathrm{~mm}$ with two maxima in May and November and summer drought (Török et al., 2000). The most typical soil types are sand with more or less humus content and saline soils. The Kiskunság region is an important biodiversity hotspot in Hungary, because of its unique native plant and animal communities on sandy areas (Török et al., 2000; Szinetár et al., 2005; Batáry et al., 2007). The region is characterised by a mosaic of natural grasslands (sandy grasslands and salt meadows), wetlands (marshes, fen meadows, and mires), and forests (sandy oak woods, poplar-juniper steppe woodlands, and floodplain forests), as well as arable fields (maize and corn) and non-native tree plantations (black locust (Robinia pseudoacacia), ennobled poplar species (Populus spp.) and pine species (Pinus spp.)). After introducing arable farming in the 18th century, the area of the natural habitats decreased significantly by the end of the last century. Nowadays, only remnants of these habitats are to be found within the fragmented landscape of the Kiskunság region. The minimum distance between the studied grassland fragments was $1 \mathrm{~km}$; the maximum distance was $44 \mathrm{~km}$, while the average distance between the fragments was $22 \mathrm{~km}$.

\subsection{Sampling design}

During the 9-year study period (2001-2009), we sampled spider species using pitfall traps. We placed 10 traps randomly in each investigated fragment. All traps were at least $50 \mathrm{~m}$ apart from the grassland edges to avoid edge effects (Horváth et al., 2002). Traps consisted of plastic cups with $100 \mathrm{~mm}$ diameter and contained about $150 \mathrm{ml}$ 70\% ethylene glycol as a killing-preserving

Table 1

Environmental factors at local and landscape-level scale of the nine studied grassland fragments in Kiskunság region.

\begin{tabular}{|c|c|c|c|c|c|c|c|}
\hline $\begin{array}{l}\text { Fragments/ } \\
\text { variables }\end{array}$ & $\begin{array}{l}\text { Cover of plants } \\
(\%)\end{array}$ & $\begin{array}{l}\text { Cover of bare ground } \\
(\%)\end{array}$ & $\begin{array}{l}\text { Cover of litter } \\
\text { (\%) }\end{array}$ & $\begin{array}{l}\text { Average height of grass } \\
(\mathrm{cm})\end{array}$ & $\begin{array}{l}\text { Patch size } \\
\text { (ha) }\end{array}$ & $\begin{array}{l}\text { Inverse isolation index } \\
\text { (ha) }\end{array}$ & $\begin{array}{l}\text { Landscape } \\
\text { diversity }\end{array}$ \\
\hline 1. Bugac-borókás & 36.7 & 49.0 & 4.3 & 29.4 & 408.0 & 556.0 & 0.261 \\
\hline 2. Bugac-legelő & 72.8 & 5.5 & 16.0 & 34.6 & 1022.4 & 688.1 & 0.372 \\
\hline 3. Fischerbócsa & 46.9 & 36.9 & 7.1 & 27.7 & 43.8 & 80.6 & 0.170 \\
\hline 4. Fülöpháza & 54.9 & 32.3 & 4.1 & 32.0 & 300.8 & 526.9 & 0.524 \\
\hline 5. Kunadacs & 54.5 & 22.0 & 17.7 & 32.0 & 3.0 & 28.5 & 0.113 \\
\hline 6. Kunbaracs east & 63.0 & 13.5 & 9.1 & 28.0 & 14.6 & 63.2 & 0.263 \\
\hline 7. Kunbaracs west & 59.6 & 14.6 & 14.8 & 33.2 & 8.6 & 57.0 & 0.148 \\
\hline 8. Orgovány & 67.8 & 15.7 & 8.5 & 30.6 & 108.0 & 185.7 & 0.365 \\
\hline 9. Soltszentimre & 42.3 & 42.7 & 7.9 & 34.3 & 175.5 & 270.7 & 0.539 \\
\hline
\end{tabular}


liquid. We protected pitfall traps by fiberboard from litter, rain, and small vertebrates. We emptied the traps fortnightly from the end of March to the end of October. We identified all adult spiders to species level, while juvenile spiders only to genus level (Nentwig et al., 2015). We followed the World Spider Catalog's nomenclature (World Spider Catalog, 2015).

\subsection{Data analyses}

Local and landscape-level factors affecting the distribution of spider assemblages were studied (Table 1 ). The local factors were the cover of plants, the cover of litter, the cover of bare ground, the average height of grass, and the patch size. We estimated these parameters in every year within a $1 \times 1 \mathrm{~m}$ quadrat next to each traps. We used the average value of these factors from the nine years for the statistical analyses. The size of the studied unmanaged dry sandy grassland fragments was measured on digitized 1:10,000 maps and aerial photographs using Quantum GIS program. Two measures of landscape composition were analyzed: (i) inverse isolation index, and (ii) landscape diversity (Table 1). We measured these factors in the first (2001) and last (2009) years of the study. Isolation of a grassland fragment is often measured as the distance to the nearest fragment, notwithstanding isolation also depends on the size of the nearest fragment. We measured the isolation of the grassland fragments by the inverse isolation index, defined as the total size of unmanaged dry sandy grasslands within buffer around the studied grassland fragment. This value decreases as the isolation of the grassland increases (Magura et al., 2001). We also identified the different vegetation patches based on aerial photographs within buffer around the studied grassland fragment. To express the landscape diversity, we calculated the Shannon diversity index based on the area of six habitat types: grasslands, wet meadows, forests, arable fields, artificial areas, and water bodies. A series of buffers with increasing distances $(100 \mathrm{~m}, 500 \mathrm{~m}, 1000 \mathrm{~m}, 2000 \mathrm{~m}, 3000 \mathrm{~m})$ from the edge of the grassland fragments around all sites were used to determine appropriate spatial scale at which the surrounding landscape is relevant and influencing the spider species richness and abundance.

We investigated the relationships between the local and landscape-level factors and the species richness and abundance of spider assemblages by generalized linear models (GLMs, StatSoft Inc., 2010) using the multiple regression design. We first fitted the full model containing all (local and landscape-level) factors. We evaluated models based on Akaike's information criterion (Akaike, 1973) and accepted the model with the lowest AIC as the final model. In the final model, the dependent variables (species richness and abundance) were regarded as following quasi-Poisson distribution (with log link function) to account for overdispersion in the data (Bolker et al., 2009). We pooled the catches of all traps for the whole year in every year and analyzed the nine years average value of all sites. The overall species richness, the total number of individuals and the species richness and abundance of habitat specialist, generalist and hunting spiders were regarded as dependent variables. We considered the following species as habitat specialists: (i) species which occur exclusively in open sandy habitats, (ii) species which occur in more open habitat types, but in lowlands can be found only in open sandy habitats. For all dependent variables, the goodness of fit of the model with the lowest AIC was the highest in case of the buffer with $1000 \mathrm{~m}$ distance from the edge of the grassland fragments; therefore, this spatial scale was used during the analyses. The number and the area of the unmanaged dry sandy grasslands within the buffer around the studied grassland fragments did not change between 2001 and 2009. Moreover, the landscape diversity did not differ significantly between the studied two years (Mann-Whitney
$U=36.00, p=0.6911, N=9$ ). Thus, we used the data from 2009 for the statistical analyses.

We examined the relationships between the local and landscape-level factors and the abundance of the nine most frequent species using the detrended canonical correspondence analysis by second order polynomials (DCCA) calculated by the CANOCO package (Lepš and Šmilauer, 2003). Biplot scaling in the ordination was focused on the inter-species distances.

\section{Results}

During the 9-year study, we collected altogether 6589 individuals of 145 species, including 46 habitat specialist species with 3008 individuals, 85 generalist species with 3314 individuals, 9 forest-associated species with 244 individuals and 5 species, which could be determined only at genus level with 23 individuals (Electronic supplementary material (ESM) Table 1). Regarding the main guild types, 6273 individuals belonged to 110 hunting species and 316 individuals represented 35 web-building species. Four of the nine most abundant species were habitat specialist (Alopecosa psammophila, Berlandia cinerea, Callilepis nocturna, and Gnaphosa mongolica), four were generalist (Alopecosa cursor, Alopecosa sulzeri, Xysticus kochi, and Zelotes longipes) and one was forestassociated species (Pardosa alacris).

The generalized linear models showed that the local factors (cover of plants, cover of litter cover of bare ground, and patch size) had more influence on spider assemblages, than the landscapelevel factors (Figs. 1-3, Tables 2 and 3). The relationship was significantly positive between the total number of species, the number of habitat specialist species, the number of habitat specialist individuals, the number of generalist individuals, and the cover of plants (Fig. 1a-d, Table 2). A significant positive relationship was found between the number of generalist individuals, the number of specialist individuals, the number of hunting species, and the cover of litter (Fig. 2a-c, Tables 2 and 3). The total number of species, the total number of individuals, the number of generalist species, the number of generalist individuals, and the number of hunting individuals decreased significantly with the increasing of the cover of bare ground (Fig. 3a-e, Tables 2 and 3). The number of generalist and specialist individuals increased significantly with the increasing of the patch size (Table 2). Total number of individuals and number of hunting individuals showed a significant negative, while the number of specialist individuals showed a significant positive relationship with the inverse isolation index (Tables 2 and 3). One studied local factor (average height of grass) and one landscape-level factor (landscape diversity) had no significant influence on any of the dependent variables (Tables 2 and 3).

The DCCA biplot showed that there was a negative relationship between the cover of bare ground and the cover of plants (Spearman's rank correlation coefficient $r=-0.9620$ ) and the cover of litter (Spearman's rank correlation coefficient $r=-0.6966$ ) (Fig. 4). The response of individual hunting species to both local and landscape-level factors was heterogeneous. The habitat specialist $A$. psammophila was positively associated with bare ground cover and negatively with plant and litter cover, while the also specialist $B$. cinerea showed an opposite reaction to these factors (Fig. 4). Neither local nor landscape-level factors influenced the distribution of the generalist species $(A$. cursor, A. sulzeri, X. kochi, and Z. longipes). Similarly, the distribution of a specialist ( $C$. nocturna) and a forest-associated species ( $P$. alacris) was not influence neither the local nor the landscape-level factors (Fig. 4). The specialist G. mongolica was the only species that responded merely to one landscape-level factor. The abundance of this species increased with the decreasing of isolation (Fig. 4). 

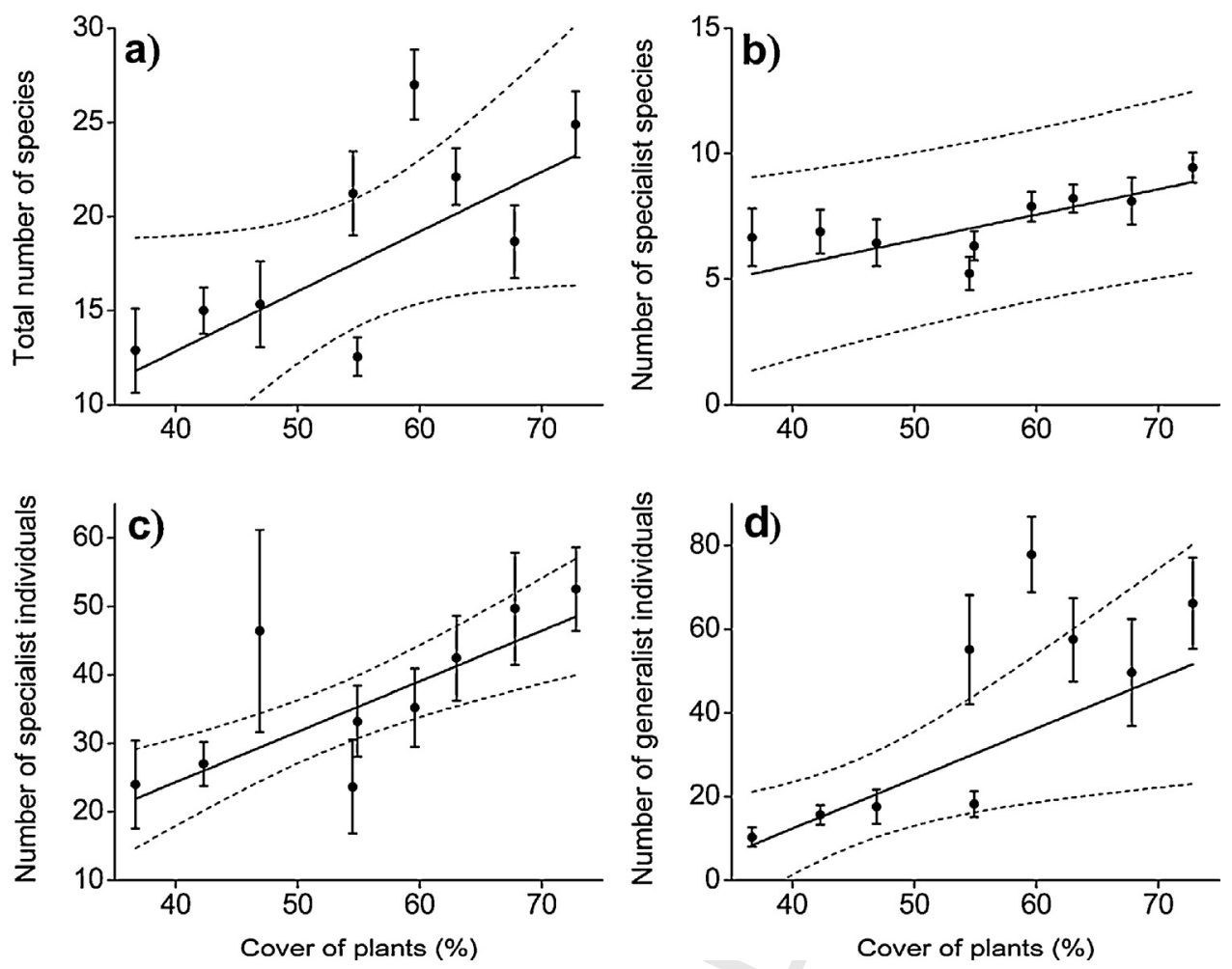

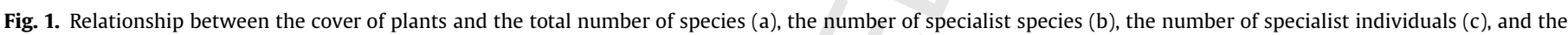
number of generalist individuals (d). Dashed lines represent the confidence bands (95\%).
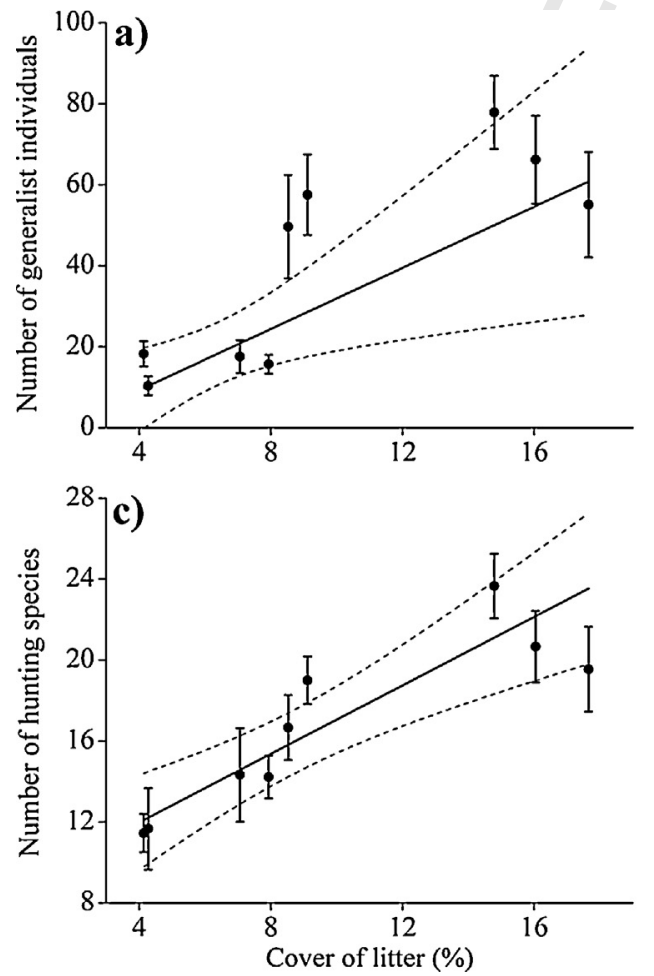

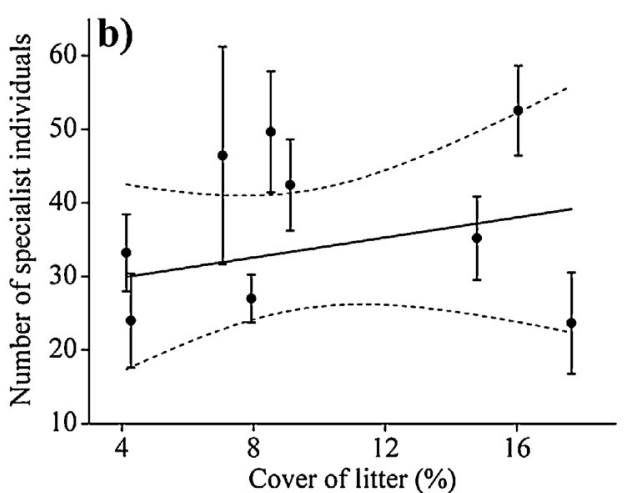

Cover of litter (\%) Dashed lines represent the confidence bands (95\%). 

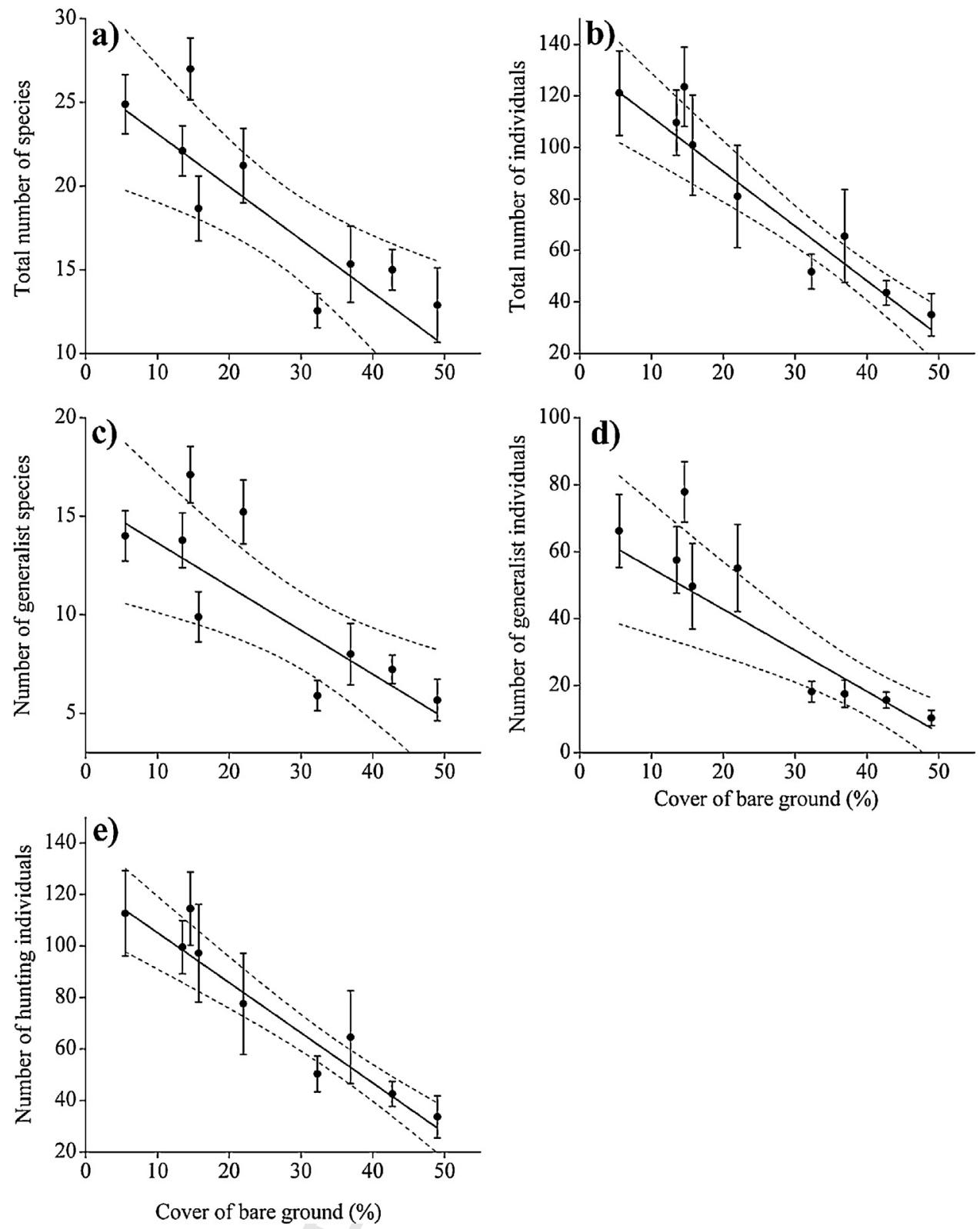

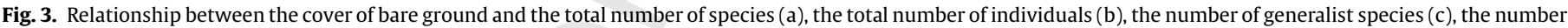
of generalist individuals (d), and the number of hunting individuals (e). Dashed lines represent the confidence bands (95\%).

Table 2

Relationship between the number of spider individuals, species and the studied factors by generalized linear models (GLMs) using the multiple regression design.

\begin{tabular}{|c|c|c|c|c|c|c|}
\hline & $\begin{array}{l}\text { Total number of } \\
\text { individuals }\end{array}$ & $\begin{array}{l}\text { Total number of } \\
\text { species }\end{array}$ & $\begin{array}{l}\text { Number of specialist } \\
\text { individuals }\end{array}$ & $\begin{array}{l}\text { Number of specialist } \\
\text { species }\end{array}$ & $\begin{array}{l}\text { Number of generalist } \\
\text { individuals }\end{array}$ & $\begin{array}{l}\text { Number of generalist } \\
\text { species }\end{array}$ \\
\hline Cover of plants & Not entered & $+* * *$ & $+* * *$ & $+* *$ & Not entered & $+* * *$ \\
\hline Cover of litter & Not entered & Not entered & $+* * *$ & Not entered & $+* * *$ & Not entered \\
\hline $\begin{array}{l}\text { Cover of bare } \\
\text { ground }\end{array}$ & $-{ }^{* * *}$ & $-{ }^{* * *}$ & Not entered & Not entered & $-^{* * *}$ & $-^{* * *}$ \\
\hline $\begin{array}{l}\text { Average height of } \\
\text { grass }\end{array}$ & Not entered & Not entered & Not entered & Not entered & Not entered & Not entered \\
\hline Patch size & Not entered & Not entered & $+* * *$ & Not entered & $+* * *$ & Not entered \\
\hline $\begin{array}{l}\text { Inverse isolation } \\
\text { index }\end{array}$ & $-^{* *}$ & Not entered & $+* * *$ & Not entered & Not entered & Not entered \\
\hline $\begin{array}{l}\text { Landscape } \\
\text { diversity }\end{array}$ & Not entered & Not entered & Not entered & Not entered & Not entered & Not entered \\
\hline
\end{tabular}

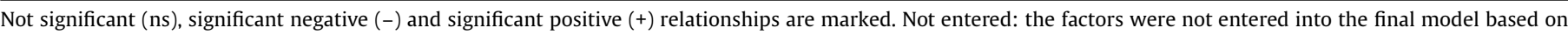
Akaike's information criterion (AIC). ${ }^{*} p<0.05,{ }^{* *} p<0.01,{ }^{* * *} p<0.001$ 
Table 3

Relationship between the number of hunting spider individuals, species and the studied factors by generalized linear models (GLMs) using the multiple regression design.

\begin{tabular}{lll}
\hline & Number of hunting individuals & Number of hunting species \\
\hline Cover of plants & Not entered & Not entered \\
Cover of litter & Not entered & $+^{* * *}$ \\
Cover of bare ground & $-{ }^{* * *}$ & Not entered \\
Average height of grass & Not entered & Not entered \\
Patch size & Not entered & Not entered \\
Inverse isolation index & $--^{*}$ & Not entered \\
Landscape diversity & Not entered & Not entered \\
\hline
\end{tabular}

Not significant (ns), significant negative (-) and significant positive (+) relationships are marked. Not entered: the factors were not entered into the final model based on Akaike's information criterion (AIC). ${ }^{*} p<0.05,{ }^{* *} p<0.01,{ }^{* * *} p<0.001$.

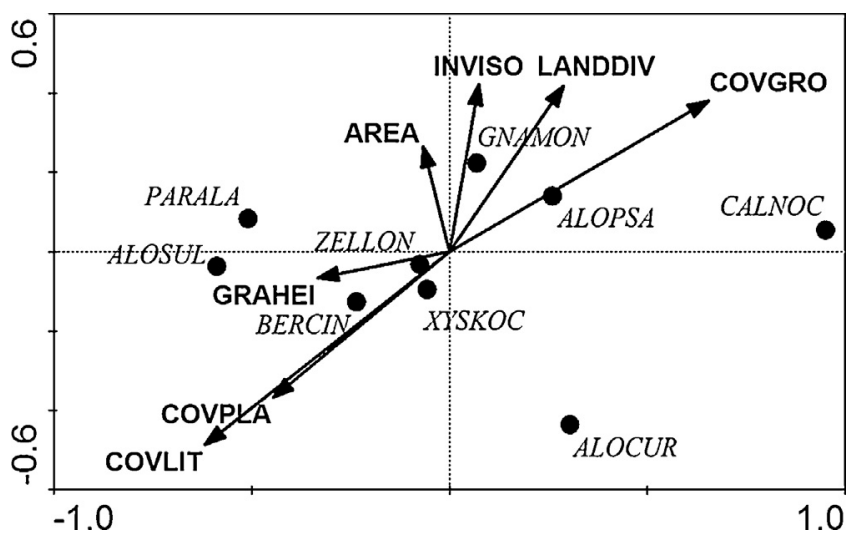

Fig. 4. DCCA for the nine most frequent spider species. The arrows point the increase of the value of the five local and three landscape-level factors (COVPLA: cover of plants; COVGRO: cover of bare ground; COVLIT: cover of litter; GRAHEI: average height of grass; AREA: patch size; INVISO: inverse isolation; and LANDDIV: landscape diversity). Filled circles and the six-letter abbreviations indicate the spider species (e.g., BERCIN: Berlandia cinerea).

\section{Discussion}

In unmanaged dry sandy grassland fragments, we investigated the effects of local and landscape-level factors on spider assemblages. We found that the local factors had stronger influence on species richness and density of spiders than landscape-level factors. Only one landscape-level factor (isolation) had effects on the total abundance and on the abundance of specialist and hunting species.

The local factors (four out of five: plant cover, litter cover, bare ground cover, and patch size) significantly affected overall, generalist, specialist, and hunting spider assemblages. The species richness and abundance were positively influenced by the plant cover, litter cover and patch size, but negatively by the bare ground cover. There are several retreats, hiding places, and numerous preys in a dense vegetation and under litter; these results in a higher species richness and abundance of spiders in the patches with higher plant and litter cover. Furthermore, the increasing plant and litter cover moderate temperature and humidity extremes contributing to the enhancement of spider diversity (Rypstra et al., 1999). Similarly to our findings Batáry et al. (2008) found a positive effect of plant and litter cover on species richness and abundance of spiders. In contrast, Warui et al. (2005) found no significant relationship between the diversity of ground-dwelling spiders and the cover of plants, studying the effects of grazing by cattle, meso-herbivores like buffalos and other smaller ungulates, and mega-herbivores like giraffes and elephants. During the analysis, the effect of herbivore species was not considered; the contrasting effect of smaller ungulates, meso- and mega-herbivores may annihilate the influence of plants' cover on spider diversity resulting in a spurious no influence. Dennis et al. (2001) studied the epigeal arachnids of Nardus stricta dominated grassland in Scotland and they emphasized that the vegetation structure (mean vegetation height) was the most important local factor which significantly influenced the species composition and abundance. Our species-level analysis showed that the specialist nocturnal hunter $B$. cinerea, which prefers the open and dry sandy grasslands (Buchar and Ruzicka, 2002) reacted positively to plant and litter cover and negatively to bare ground cover. This spider needs some vegetation including lichens, and litter as hiding place, because this species takes shelter among vegetation and under litter not in the soil in the daytime (Buchar and Ruzicka, 2002).

We found that the bare ground cover decreased the diversity of the spider assemblages. Most of spiders have conspicuous coloration and markings, and they can not find suitable shelter away from predators if the soil surface becomes open. The abundance and species richness of these species decrease with the increase of bare ground cover (Wu et al., 2009). The intense management in grasslands increases the cover of bare ground, which causes the decrease of the diversity of spider assemblages and the increase of the dominance of a few r-selected species; this initial colonizing species are very mobile and less demanding toward habitat features (Bell et al., 2001). In our study, the abundance of sand specialist $A$. psammophila positively correlated with bare ground cover and negatively with plant and litter cover. Our findings suggest that this species occurs in high number only in those fragments where the ratio of the bare sand surfaces is considerably high.

Patch size influenced both the number of generalist and specialist abundance. The abundance of these spiders increased with the patch size. Galle (2008) also reported that the abundance of generalist and specialist spiders increased with patch size. It is likely that both generalist and specialist species need a minimum habitat size for a viable population. The abundance of these species decreased with the decrease of patch size suggesting that they were not able to settle down permanently in the smaller fragments. It is likely that, these spiders can survive and reproduce with major chance only in the larger grassland fragments.

We found that isolation was the only landscape-level factor which influenced the abundance of spiders. The overall spider abundance and the abundance of hunting species increased, while the abundance of specialist species and the abundance of specialist G. mongolica decreased as isolation of the grassland fragments increased. The neighboring habitats around the more isolated fragments may function as the source habitats in case of generalist, forest-associated and hunting species; therefore, these spiders can colonize the more isolated unmanaged dry sandy grassland fragments from the agricultural and forested lands. However, habitat specialist spiders could not settle down permanently in the adjacent arable lands and non-native tree plantations, because these habitats were unfavorable for them. These habitats functioned as barriers for specialist species, thus, their abundance 
was lower in the more isolated fragments. Several earlier studies emphasized the role of the landscape-level factors such as percentage of grasslands, percentage of non-crop habitats and landscape diversity on the species richness and abundance of spiders in arable lands (Clough et al., 2005; Schmidt et al., 2008; Öberg et al., 2007; Concepción et al., 2008; Pluess et al., 2010). The factors at the landscape-level scale (percentage of intensively used agricultural areas, percentage of forests, and landscape diversity) also influenced the diversity of spiders more considerably in seminatural grasslands than local factors (Hendrickx et al., 2007; Batáry et al., 2012; Miyashita et al., 2012; Zulka et al., 2014). Landscape composition (percentage of grasslands or non-crop habitats) is the most important in shaping spider composition and diversity in arable lands because surrounding natural and semi-natural grasslands provides overwintering habitats or refuges for many spider species (Clough et al., 2005; Schmidt et al., 2005, 2008; Öberg et al., 2007; Concepción et al., 2008; Pluess et al., 2010). Arable lands serve only as sink habitat for most spider species due to consecutive disturbances such as tillage (ploughing and hoeing), soil fertilizing, chemical treatments, and harvesting (Drapela et al., 2008; Öberg et al., 2007). Thus, the extinction and recolonization repeat continuously. Likewise, the semi-natural managed grasslands also have not stable spider assemblages because of periodical intensive managements like grazing and mowing (Hendrickx et al., 2007; Batáry et al., 2012; Miyashita et al., 2012; Zulka et al., 2014). Therefore, also in case of these habitats, the influence of landscapelevel factors is more important than local factors on spider assemblages. In contrast to, based on our results, it seems that the studied very extensive unmanaged dry sandy grasslands maintain stable and species rich spider assemblages. A likely reason for this is that the colonizing species have a competitive disadvantage; thus, the assemblage shaping effect of the local factors becomes much more important. Therefore, the local factors are more important limiting factors for species richness and/or abundance in these grasslands than in disturbed and managed habitats.

\section{Conclusions}

Dry sandy grasslands are typical and one of the most valuable habitat type in the Kiskunság area. This habitat type, the Pannonic sand steppe is listed in the Habitats Directive of the European Union as a priority habitat type, and the protection of these grasslands has high priority both on national and international levels. Spiders, as generalist predators play an important role in supporting the biodiversity and functioning of this grassland type. We found that local features were the most important predictors for the species richness and abundance of spiders in the studied unmanaged grassland fragments, and the influence of landscapelevel features was limited at assemblage level. We also found that the influence of local factors was more important at species level, especially for the habitat specialist species. Just the opposite is reported for agricultural landscapes where the landscape-level factors are more important supporting the spider assemblages than the local factors. Our findings also highlight that the species pool is probably supported by the viable populations of the grassland fragments in unmanaged grasslands. This is not the case for managed grasslands where the landscape-level factors and the continuous re-establishment of the spider assemblage is a key factor in supporting the species richness. Thus, our finding reveals that the preservation of these unmanaged grassland fragments is vital, because these fragments serve as colonization sources for the surrounding arable lands. Intensive managements should be avoided, since these activities alter the composition of spider assemblages and decrease the number of specialist and valuable species in these natural fragments.

\section{Acknowledgements}

The authors wish to thank Dr. Viktor Markó, the organizer of the National Biodiversity Monitoring System. This study was part of the National Biodiversity Monitoring System in Hungary funded by the Ministry of Rural Development. The work was supported by TAMOP-4.2.2/B-10/1-2010-0024, and TAMOP-4.2.2.C-11/1/KONV2012-0010 projects.

\section{Appendix A. Supplementary data}

Supplementary data associated with this article can be found, in the online version, at http://dx.doi.org/10.1016/j.agee.2015.04.033.

\section{References}

Akaike, H., 1973. Information theory as an extension of the maximum likelihood principle. In: Petrov, B.N., Csaki, F. (Eds.), Second International Symposium on Information Theory, Akadémiai Kiadó, Budapest, pp. 267-281.

Batáry, P., Orci, K.M., Báldi, A., Kleijn, D., Kisbenedek, T., Erdős, S., 2007. Effects of local and landscape scale and cattle grazing intensity on Orthoptera assemblages of the Hungarian Great Plain. Basic Appl. Ecol. 8, 280-290.

Batáry, P., Báldi, A., Samu, F., Szűts, T., Erdős, S., 2008. Are spiders reacting to local or landscape scale effects in Hungarian pastures? Biol. Conserv. 141, 2062-2070.

Batáry, P., Holzschuh, A., Orci, K.M., Samu, F., Tscharntke, T., 2012. Responses of plant, insect and spider biodiversity to local and landscape scale management intensity in cereal crops and grasslands. Agric. Ecosyst. Environ. 146, 130-136.

Bell, J.R., Wheater, C.P., Cullen, W.R., 2001. The implications of grassland and heathland management for the conservation of spider communities: a review. J. Zool. 255, 377-387.

Bolker, B.M., Brooks, M.E., Clark, C.J., Geange, S.W., Poulsen, J.R., Stevens, M.H., White, J.S., 2009. Generalized linear mixed models: a practical guide for ecology and evolution. Trends Ecol. Evol. 24, 127-135.

Buchar, J., Ruzicka, V., 2002. Catalogue of Spiders of the Czech Republic, first ed. Peres Publishers, Praha.

Buchholz, S., 2010. Ground spider assemblages as indicators for habitat structure in inland sand ecosystems. Biodivers. Conserv. 19, 2565-2595.

Cattin, M.F., Blandenier, G., Banašek-Richter, C., Bersier, L.F., 2003. The impact of mowing as a management strategy for wet meadows on spider (Araneae) communities. Biol. Conserv. 113, 179-188.

Clough, Y., Kruess, A., Kleijn, D., Tscharntke, T., 2005. Spider diversity in cereal fields: comparing factors at local, landscape and regional scales. J. Biogeogr. 32, $2007-$ 2014.

Concepción, E.D., Díaz, M., Baquero, R.A., 2008. Effects of landscape complexity on the ecological effectiveness of agri-environment schemes. Landscape Ecol. 23, 135-148.

Dengler, J., Janišová, M., Török, P., Wellstein, C., 2014. Biodiversity of Palaearctic grasslands: a synthesis. Agric. Ecosyst. Environ. 182, 1-14.

Dennis, P., Young, M.R., Bentley, C., 2001. The effects of varied grazing management on epigeal spiders, harvestmen and pseudoscorpions of Nardus stricta grassland in upland Scotland. Agric. Ecosyst. Environ. 86, 39-57.

Drapela, T., Moser, D., Zaller, J.G., Frank, T., 2008. Spider assemblages in winter oilseed rape affected by landscape and site factors. Ecography 31, 254-262.

Gallé, R., 2008. The effect of a naturally fragmented landscape on the spider assemblages. North-West. J. Zool. 4, 61-71.

Heikkinen, M.W., MacMahon, J.A., 2004. Assemblages of spiders on models of semiarid shrubs. J. Arachnol. 32, 313-323.

Hendrickx, F., Maelfait, J.P., van Wingerden, W., Schweiger, O., Speelmans, M., Aviron, S., Augenstein, I., Billeter, R., Bailey, D., Bukacek, R., Burel, F., Diekotter, T., Dirksen, J., Herzog, F., Liira, J., Roubalova, M., Vandomme, V., Bugter, R., 2007. How landscape structure, land-use intensity and habitat diversity affect components of total arthropod diversity in agricultural landscapes. J. Appl. Ecol. $44,340-351$.

Hooftman, D.A.P., Bullock, J.M., 2012. Mapping to inform conservation: a case study of changes in semi-natural habitats and their connectivity over 70 years. Biol. Conserv. 145, 30-38.

Horváth, R., Magura, T., Péter, G., Tóthmérész, B., 2002. Edge effect on weevils and spiders. Web Ecol. 3, 43-47.

Horváth, R., Lengyel, S., Szinetár, C., Jakab, L., 2005. The effect of prey availability on spider assemblages on black pine (Pinus nigra) bark: spatial patterns and guild structure. Can. J. Zool. 83, 324-335.

Horváth, R., Magura, T., Szinetár, C., Tóthmérész, B., 2009. Spiders are not less diverse in small and isolated grasslands, but less diverse in overgrazed grasslands; a field study (East Hungary, Nyárseg). Agric. Ecosyst. Environ. 130, $16-22$.

Horváth, R., Magura, T., Tóthmérész, B., 2012. Ignoring ecological demands masks the real effect of urbanization: a case study of ground-dwelling spiders along a rural-urban gradient in a lowland forest in Hungary. Ecol. Res. 27, 1069-1077. 
G Model

AGEE 5030 1-8

8

R. Horváth et al./Agriculture, Ecosystems and Environment $x x x$ (2015) $x x x-x x x$

474
475
47
47
478
479
480
48
48
48
48
485
48
487
488
489
490
49
492
493
494
495
49
49
497
499
500
50
502
503
504
505
50
50

Horváth, R., Magura, T., Szinetár, C., Eichardt, J., Tóthmérész, B., 2013. Large and least isolated fragments preserve habitat specialist spiders best in dry sandy grasslands in Hungary. Biodivers. Conserv. 22, 2139-2150.

Jeanneret, P., Schüpbach, B., Pfiffner, L., Walter, T., 2003. Arthropod reaction to landscape and habitat features in agricultural landscapes. Landscape Ecol. 18 253-263.

Krauss, J., Bommarco, R., Guardiola, M., Heikkinen, R.K., Helm, A., Kuussaari, M., Lindborg, R., Ockinger, E., Pärtel, M., Pino, J., Pöyry, J., Raatikainen, K.M., Sang, A., Stefanescu, C., Teder, T., Zobel, M., Steffan-Dewenter, I., 2010. Habitat fragmentation causes immediate and time-delayed biodiversity loss at different trophic levels. Ecol. Lett. 13, 597-605.

Lepš, J., Šmilauer, P., 2003. Multivariate Analysis of Ecological Data Using CANOCO, first ed. Cambridge University Press, Cambridge.

Magura, T., Ködöböcz, V., Tóthmérész, B., 2001. Effects of habitat fragmentation on carabids in forest patches. J. Biogeogr. 28, 129-138.

Malumbres-Olarte, J., Barratt, B.I.P., Vink, C.J., Paterson, A.M., Cruickshank, R.H., Ferguson, C.M., Barton, D.M., 2014. Big and aerial invaders: dominance of exotic spiders in burned New Zealand tussock grasslands. Biol. Invasions 16, 23112322.

Miyashita, T., Chishiki, Y., Takagi, S.R., 2012. Landscape heterogeneity at multiple spatial scales enhances spider species richness in an agricultural landscape.

Popul. Ecol. 54, 573-581.
Q15 Nentwig, W., Blick, T., Gloor, D., Hänggi, A., Kropf, C., 2015. Spiders of Europe, $<$ http://www.araneae.unibe.ch/> (accessed 01.15.).

Öberg, S., Ekbom, B., Bommarco, R., 2007. Influence of habitat type and surrounding landscape on spider diversity in Swedish agroecosystems. Agric. Ecosyst. Environ. 122, 211-219.

Pluess, T., Opatovsky, I., Gavish-Regev, E., Lubin, Y., Schmidt-Entling, M.H., 2010. Non-crop habitats in the landscape enhance spider diversity in wheat fields of a desert agroecosystem. Agric. Ecosyst. Environ. 137, 68-74.

Rypstra, A.L., Carter, P.E., Balfour, R.A., Marshall, S.D., 1999. Architectural features of agricultural habitats and their impact on the spider inhabitants. J. Aarachnol. 27, 371-377.

Schirmel, J., Timler, L., Buchholz, S., 2011. Impact of the invasive moss Campylopus introflexus on carabid beetles (Coleoptera: Carabidae) and spiders (Araneae) in acidic coastal dunes at the southern Baltic Sea. Biol. Invasions 13, 605-620.

Schmidt, M.H., Roschewitz, I., Thies, C., Tscharntke, T., 2005. Differential effects of landscape and management on diversity and density of ground-dwelling farmland spiders. J. Appl. Ecol. 4, 281-287.
Schmidt, M.H., Thies, C., Nentwig, W., Tscharntke, T., 2008. Contrasting responses of arable spiders to the landscape matrix at different spatial scales. J. Biogeogr. 35 , 157-166.

StatSoft Inc., 2010. STATISTICA for Windows, Version 12.5. StatSoft Inc., Tulsa. Szinetár, C., Eichardt, J., Horváth, R., 2005. Data on the biology of Alopecosa psammophila Buchar 2001 (Araneae, Lycosidae). J. Arachnol. 33, 384-389.

Török, K., Szili-Kovács, T., Halassy, M., Tóth, T., Hayek, Z., Paschke, M.W., Wardell, L.J., 2000. Immobilization of soil nitrogen as a possible method for the restoration of sandy grassland. Appl. Veg. Sci. 3, 7-14.

Tscharntke, T., Klein, A.M., Kruess, A., Steffan-Dewenter, I., Thies, C., 2005. Landscape perspectives on agricultural intensification and biodiversity - ecosystem service management. Ecol. Lett. 8, 857-874.

Tscharntke, T., Tylianakis, J.M., Rand, T.A., Didham, R.K., Fahrig, L., Batáry, P., Bengtsson, J., Clough, Y., Crist, T.O., Dormann, C.F., Ewers, R.M., Fründ, J., Holt, R. D., Holzschuh, A., Klein, A.M., Kleijn, D., Kremen, C., Landis, D.A., Laurance, W., Lindenmayer, D., Scherber, C., Sodhi, N., Steffan-Dewenter, I., Thies, C., van der Putten, W.H., Westphal, C., 2012. Landscape moderation of biodiversity patterns and processes - eight hypotheses. Biol. Rev. 87, 661-685.

Varga, Z., 1997. Dry grasslands of the Pannonian lowland: relation of physiognomic structure and floristic composition to certain insect groups. Phytocoenologia 27, 509-571.

Warui, C.M., Villet, M.H., Young, T.P., Jocqué, R., 2005. Influence of grazing by large mammals on the spider community of a Kenyan savanna biome. J. Arachnol. 33, 269-279.

Wise, D.H., 1993. Spiders in Ecological Webs, first ed. Cambridge University Press, Cambridge.

Woodcock, B.A., Pywell, R.F., Roy, D.B., Rose, R.J., Bell, D., 2005. Grazing management of calcareous grasslands and its implications for the conservation of beetle communities. Biol. Conserv. 125, 192-202.

World Spider Catalog, 2015. Natural History Museum Bern. <http://wsc.nmbe.ch/>, version 15.5 (accessed 01.15.).

Wu, Y., Cai, Q., Lin, C., Chen, Y., Li, Y., Cheng, X., 2009. Responses of ground-dwelling spiders to four hedgerow species on sloped agricultural fields in Southwest China. Prog. Nat. Sci. 19, 337-346.

Zulka, K.P., Abensperg-Traun, M., Milasowszky, N., Bieringer, G., Gereben-Krenn, B. A., Holzinger, W., Hölzler, G., Rabitsch, W., Reischütz, A., Querner, P., Sauberer, N., Schmitzberger, I., Willner, W., Wrbka, T., Zechmeister, H., 2014. Species richness in dry grassland patches of eastern Austria: a multi-taxon study on the role of local, landscape and habitat quality variables. Agric. Ecosyst. Environ. 182, 25-36.

512
513
514
515
516
517
518

519
520
521
522
523
524

525
526
527
528
529
530
531
532
533
534
535
536
537
538
539
540
541
542
543
544

545
546
547
548

Please cite this article in press as: Horváth, R., et al., In stable, unmanaged grasslands local factors are more important than landscape-level

factors in shaping spider assemblages. Agric. Ecosyst. Environ. (2015), http://dx.doi.org/10.1016/j.agee.2015.04.033 